\title{
MUATAN KEPENTINGAN POLITIK PENENTU KUALITAS UNDANG-UNDANG
}

\author{
Ferry Irawan Febriansyah \\ Fakultas Hukum Universitas Muhammadiyah Ponorogo \\ e-mail: irawanferryirawan@yahoo.com
}

\begin{abstract}
ABSTRAK
Dalam politik hukum, wewenang yang diberikan kepada para elit politik untuk membentuk suatu peraturan seringkali dijadikan alat untuk mencapai kepentingan politik mereka. Aspirasi rakyat sering terlupakan akibat terlalu sibuknya para elit politik dalam mengurusi partai politiknya. Keinginan masyarakat tertuju pada keadilan yang memberikan keseimbangan dalam kehidupan bermasyarakat. Jika kepastian hanya tergantung dari muatan kepentingan politik maka kualitas undang-undang patut diragukan. Kesejahteraan tidak akan tercapai jika kualitas undang-undang dilandasi muatan kepentingan-kepentingan politik bukan kepentingan masyarakat banyak. Jika sudah terjadi demikian, maka konstitusi hanya menjadi hiasan negara bukan menjadi pedoman dalam menciptakan undang-undang demi kepastian, keadilan dan manfaat. Pancasila merupakan sumber dari segala sumber hukum yang ada di Indonesia yang mengartikan bahwa semua hukum yang ada dan berlaku di Indonesia harus sesuai dengan nilai-nilai dari Pancasila yang mengedepankan kepentingan rakyat.
\end{abstract}

Kata Kunci: politik, hukum, keadilan, konstitusi, kepentingan politik.

\begin{abstract}
In law politics, the authority which is given to the political elite to establish a regulation is often used as a tool to achieve their political interest. People aspirations got forgotten very often due to political elites are too busy to take care of his political party. Public interest focused on justice that provides a balance in social life. If certainty was only depended on political interest, the quality of the regulations will be doubtful. Prosperity will not be achieved if the quality of the regulations is based on the charge of political interests and not the community interests. In case of this situation, state constitution will just be such a state decoration, whereas it should be a guidance in creating regulations for the sake of certainty, fairness and benefits. Pancasila is the source of all Indonesia law sources, which means that all existing laws, regulations and policies in Indonesia must be in accordance with the values of Pancasila that count heavily on the Indonesian people.
\end{abstract}

Keywords: politics, law, regulations, justice, constitution, political interest.

\section{PENDAHULUAN}

Pada asasnya, hukum terdiri peraturan-peraturan yang mana digunakan untuk mencapai kehidupan bermasyarakat agar menjadi tentram, aman, damai dan sejahtera. Definisi mengenai hukum kata Van Apeldoorn adalah sangat sulit untuk dibuat, karena tidak mungkin untuk mengadakannya yang sesuai dengan kenyataan (L. J. Van Apeldoorn, 1985:13). Akan tetapi Kafrawi mendefinisikan bahwa hukum merupakan peraturan yang dibuat oleh pemerintah, bersifat memaksa, berlaku pada waktu tertentu, tempat tertentu dan pelanggarannya dapat dikenakan sanksi atau pidana (Kafrawi, 2009).

Hukum atau undang-undang merupakan hasil kesepakatan antara penguasa dan masyarakat untuk mewujudkan kepastian, keadilan dan juga distribusi manfaat. Hukum juga merupakan sarana yang dipakai untuk tercapai tujuan tertentu. Dalam politik hukum yaitu proses dari pembuatan undang-undang, hukum dijadikan motor dalam meraih tujuan politik tertentu. Dalam politik hukum, penciptaan hukum ini memang sudah dilakukan berulang-ulang sejak adanya politik menjadi satu dengan kepentingan Negara. Politik hukum merupakan penentu dapat terciptanya undangundang yang disepakati demi kepentingan masyarakat yang berkepastian, berkeadilan serta mendistribusikan manfaat.

Cita-cita dari politik hukum merupakan tujuan demi kepentingan untuk masyarakat banyak. Politik 
hukum selalu merupakan suatu agenda kepentingan bersama. Politik hukum selalu memiliki misi utama untuk meletakkan fondasi bagi pengabdian pada kepentingan bersama. Politik hukum berpegang pada idealisme yakni melayani publik (Bernar L. Tanya, 2011:10). Melihat gejala yang ada, yaitu muatan kepentingan-kepentingan politik dalam politik hukum yang menentukan kualitas undang-undang, hal inilah yang menjadi problematika permasalahan yang ada di negara kita yang nantinya membuat undang-undang yang ada tidak berkualitas dan jauh menyimpang dari dasar negara kita karena ada permasalahan politik di dalamnya.

Permasalahan muatan kepentingan inilah yang menjadi beban bagi terciptanya perundang-undangan yang pro rakyat. Jelas antara keinginan rakyat dengan kehendak penguasa selalu kontra dalam pandangan serta dalam implementasi pelaksanaan di lapangan. Dalam tulisan ini penulis menitikberatkan tentang pemahaman akan undang-undang yang selalu dimuati oleh kepentingan politik sehingga tidak sesuai dengan kehendak dan keinginan masyarakat banyak. Jelas jika sudah terjadi demikian, maka munculah permasalahan hukum yang nantinya bukannya mensejahterakan masyarakat tetapi malah dapat menambah beban berat masyarakat dalam rangka menciptakan kehidupan yang aman, tertib dan kondusif.

Jika permasalahan akan muatan kepentingan yang mendasari terciptanya undang-undang tidak segera diselesaikan, maka akan timbul dampak negatif dalam pelaksanaan atau law enforcement undang-undang yang ada karena law making sudah dipenuhi dengan keinginan politik bukan keinginan bersama. Perlunya pembenahan dan pemahaman konstitusi yang lebih mendalam dalam terciptanya suatu undang-undang yang pro terhadap rakyat. Permasalahan ini yang nantiya akan dianalisis dan dicarikan penyelesaian di dalam tulisan ini untuk sedikit banyak membantu terciptanya perundang-undangan yang mana sesuai dengan norma-norma yang ada dalam jiwa bangsa Indonesia.

\section{PERUMUSAN MASALAH}

Dalam proses perubahan hukum, politik hukum dalam menciptakan undang-undang bertujuan demi kepastian, keadilan dan mendistribusikan manfaat. Tujuan ini seringkali justru digunakan untuk meraih keinginan-keinginan politik demi kepentingan partai politik semata sehingga melupakan aspirasi rakyat yang sebelumnya disepakati. Muatan kepentingan inilah yang akan menjadi suatu permasalahan dalam penentu terciptanya undang-undang, sehingga hasil putusan atau hasil dari politik hukum yaitu undangundang berdasarkan suara partai terbanyak yaitu $50 \%+1$. Partai yang mendominasi legislatif adalah partai yang banyak menentukan isi undang-undang sehingga dominan dengan kepentingan-kepentingan politik semata bukan untuk kepentingan rakyat pada umumnya. Permasalahan inilah yang merupakan titik tolak kualitas undang-undang yang tidak sesuai dengan norma yang ada di dalam masyarakat.

\section{METODE PENELITIAN}

Berdasar latar belakang dan tujuan pengkajian yang telah dikemukakan di atas, jenis metode yang digunakan adalah metode penelitian kualitatif yang mana pada dasarnya bersifat deskriptif dan cenderung menggunakan metode analisis dengan menggunakan pendekatan induktif (Jujun S. Suriasumantri, 2009: 48). Sedangkan dalam penelitian hukum ini menurut Ali, bahwa penelitian yuridis normatif yang bersifat kualitatif adalah penelitian yang mengacu pada norma hukum yang terdapat dalam peraturan perundangundangan dan putusan pengadilan serta norma-norma yang hidup dan juga berkembang dalam masyarakat (Zainuddin Ali, 2010:105). Laporan penelitian yang kualitatif disusun dalam bentuk narasi yang bersifat kreatif dan mendalam serta menunjukkan ciri-ciri alaminya (Bambang Dwiloka, 205:65). Bila dilihat dari jenisnya penelitian ini termasuk ke dalam jenis penelitian hukum yang non-doktrinal non socio-legal research (Peter Mahmud Marzuki, 2006:87), karena hukum dikonsepsikan sebagai manifestasi maknamakna simbolik dari para pelaku sosial sebagaimana tampak dalam interaksi antar mereka (Soetandyo Wignjosoebroto, 2002:148-176). Inti titik tekannya adalah untuk menemukan teori-teori mengenai proses terjadinya dan mengenai proses bekerjanya hukum di masyarakat (Bambang Sunggono, 2002:43). Jenis penelitian ini berawal dari kerangka teori, gagasan para ahli, ataupun berdasarkan pengalaman peneliti, kemudian dikembangkan menjadi permasalahanpermasalahan dan beserta pula dengan pemecahanpemecahannya yang diajukan untuk memperoleh verifikasi dalam bentuk bahan hukum di lapangan.

Pengambilan akan sampel sumber bahan hukum dilakukan secara Purposive dan Snowball, teknik pengumpulan triangulasi (gabungan), dan analisis bahan hukumnya bersifat induktif atau kualitatif, serta hasil penelitian kualitatif lebih menekankan makna daripada generalisasi. Jenis penelitian yang digunakan dalam penelitian ini adalah penelitian kualitatif. Metode penelitian kualitatif sering disebut metode penelitian naturalistik karena penelitiannya 
dilakukan pada kondisi yang alamiah atau natural. Disebut sebagai metode kualitatif, itu karena bahan hukum yang terkumpul dan analisisnya lebih bersifat kualitatif. Filsafat postpositivisme sering juga disebut sebagai paradigma interpretif dan konstruktif, yang mana memandang realitas sosial sebagai sesuatu yang holistik atau utuh, kompleks, dinamis, penuh makna, dan hubungan gejala bersifat interaktif atau reciprocal.

Metode penelitian kualitatif digunakan dalam penelitian ini, karena umumnya permasalahannya belum jelas, holistik, dinamis, dan penuh makna sehingga tidak mungkin bahan hukum pada situasi sosial tersebut diperoleh dengan metode penelitian kuantitatif dengan instrumen seperti test, kuesioner, pedoman wawancara. Selain itu peneliti bermaksud memahami situasi sosial dengan cara mendalam, menemukan pola, hipotesis dan teori.

\section{PEMBAHASAN}

Dalam penerapan di masyarakat, tidaklah lepas dengan apa yang disebut dengan keadilan. Keadilan inilah yang sangat ditung-tunggu kehadirannya oleh masyarakat agar dapat melakukan suatu perubahan di dalam masyarakat yang berkeadilan. Berbicara mengenai suatu teori hukum yang relevan dengan keadilan, teori-teori Hukum Alam sejak Socrates hingga Francois Geny, tetap juga mempertahankan keadilan sebagai mahkota hukum. Teori Hukum Alam mengutamakan the search for justice (Theo Huijbers, 1995:196). Terdapat macam-macam teori mengenai keadilan dan masyarakat yang adil. Teori-teori ini menyangkut hak dan kebebasan, peluang kekuasaan, pendapatan dan kemakmuran. Di antara teori-teori itu dapat disebut Teori Keadilan Aristoteles dalam bukunya nicomachean ethics dan Teori Keadilan Sosial John Rawl di dalam bukunya a Theory of Justice.

Aristoteles menuntut pelakuan yang sama bagi mereka yang sederajat dalam hukum (W. Friedmann, 1990:65). Teori keadilan menurut Aristoteles ialah pendapat bahwa keadilan itu harus dipahami dalam pengertian kesamaan. Namun Aristoteles membuat pembedaan yang penting antara kesamaan numerik dengan kesamaan proporsional. Kesamaan numerik mempersamakan setiap manusia sebagai satu unit. Inilah yang sekarang kerapkali kita pahami tentang kesamaan dan juga kita maksudkan pada saat kita mengatakan bahwa semua warga adalah sama di hadapan hukum. Kesamaan proporsional memberi tiap orang apa yang menjadi haknya sesuai dengan kemampuannya, prestasinya, dan sebagainya. Dari pembedaan ini Aristoteles menghadirkan banyak kontroversi dan perdebatan seputar keadilan (Ahmad Zaenal Fanani).

Selanjutnya untuk teori keadilan Rawls dapat disimpulkan memiliki inti yang mana sebagai berikut: 1. Memaksimalkan kemerdekaan. Pembatasan ini hanya untuk kepentingan kemerdekaan itu sendiri; 2. Kesetaraan bagi semua orang, baik kesetaraan dalam kehidupan sosial maupun kesetaraan dalam bentuk pemanfaatan kekayaan alam atau social goods. Pembatasan dalam hal ini hanya dapat dizinkan bila ada kemungkinan untuk keuntungan yang lebih besar; 3. Kesetaraan kesempatan dalam hal kejujuran, dan penghapusan terhadap ketidaksetaraan berdasarkan kelahiran dan kekayaan (Teori Keadilan John Rawls, Pemahaman Buku A Theory of Justice).

Untuk memberikan jawaban atas hal tersebut, Rawls melahirkan 3 (tiga) prinsip keadilan, yang sering dijadikan rujukan oleh beberapa ahli yakni: 1. Prinsip kebebasan yang sama atau equal liberty of principle. Bahwa setiap orang mempunyai hak yang sama atas kebebasan dasar yang paling luas, seluas kebebasan yang sama bagi semua orang; 2 . Prinsip akan perbedaan atau differences principle. Perbedaan bukan merupakan halangan untuk mencapai suatu keadilan; 3. Prinsip persamaan akan kesempatan atau equal opportunity principle. Diharapkan memberi keuntungan bagi semua orang, dan semua posisi dan jabatan terbuka bagi semua orang.

Kedua teori hukum di atas telah memberikan gambaran yang luas bagi terciptanya hukum yang berkeadilan. Keadilan hukum dalam teori di atas sangat dibutuhkan agar dapat melakukan perubahan masyarakat yang berkeadilan. Selain keadilan, hukum juga membutuhkan akan asas kepastian dan manfaat. Dalam masa perubahan dalam masa reformasi seperti sekarang ini, semakin banyak tujuan-tujuan dalam penerapan hukum di dalam kehidupan bermasyarakat. Di samping untuk mencapai keadilan, hukum juga mempunyai tujuan yaitu untuk menciptakan kepastian hukum dan mendistribusikan manfaat bagi masyarakat luas. Hukum kaitannya dengan hal ini. hukum harus bisa menyelaraskan antara unsur keadilan, kepastian dan manfaat. Sebab, seringkali antara keadilan dan kepastian hukum sering kali bertentangan satu sama lain sehingga tidak timbul distribusi manfaat yang diraih oleh masyarakat. Permasalah seperti ini di dalam ilmu hukum sering dikenal dengan summum ius summa iniura artinya keadilan tertinggi adalah ketidakadilan yang tertinggi. Maka, hukum harus mensejajarkan keadilan dan kepastian sehingga timbul manfaat yang baik bagi perubahan masyarakat. 


\section{Landasan Hukum}

Undang-Undang Dasar Tahun 1945 (selanjutnya disebut UUD 45) merupakan landasan atau dasar bagi terciptanya perundang-undangan yang ada di Indonesia. UUD 45 merupakan konstitusi yang mana ditulis dan dijadikan induk dari perundang-undangan yang ada. Dalam politik hukum, terciptanya undangundang harus bertumpu kepada UUD 45 walaupun UUD 45 ini bisa menjadi sasaran bagi politik hukum tersebut dalam mengalami perubahan. Adapun dalam perubahan UUD 45 ada pada Pasal 37 UUD 45.

Pancasila juga merupakan salah satu landasan hukum terciptanya suatu undang-undang. Di dalam Pancasila telah diatur sila-sila yang mencerminkan sikap dan juga tindak-tanduknya bangsa Indonesia yang kemudian dijadikan sebagai pedoman dalam pembuatan suatu undang-undang. Undang-undang yang baik adalah undang-undang yang mencerminkan sikap yang berasaskan sila-sila dari Pancasila yang mengutamakan kepentingan rakyat demi tercapainya kepastian, keadilan dan manfaat yang bertumpu pada kesejahteraan.

Produk perundang-undangan adalah produk dari pemerintahan suatu negara yang berfungsi untuk menata tata kehidupan masyarakat agar terciptanya suasana aman, tertib, kondusif dan juga terkendali. Seiring dengan berjalannya suatu undang-undang yang berlaku, pemegang kekuasaan senantiasa dan terus menerus memperbaharui undang-undang demi meraih tujuan yaitu tujuan hukum dan diterapkan di dalam masyarakat. Seringkali tujuan ini dimanfaatkan oleh elit politik dalam menciptakan suatu produk perundang-undangan.

Tujuan-tujuan politik dalam penerapan hukum di masyarakat inilah yang menjadi dominasi para elit politik dalam mencapai tujuan atau keinginannya. Dengan melihat tujuan yang lebih mementingkan individu partai masing-masing maka kualitas undangundang ini perlu dipertanyakan. Keputusan pembuatan undang-undang ada di tangan para elit politik, jika keputusan ini masih tetap diselingi tujuan tertentu justru demi kepentingan partai atau diri sendiri, maka kualitas undang-undang inilah yang menjadi problem utama dalam terciptanya hukum di masyarakat.

Selain melihat dari kepentingan partai tertentu dan kepentingan politik, suara terbanyak juga menentukan hasil dari undang-undang. Bila musyawarah tidak mencapai mufakat maka votinglah yang menjadi jalan terakhir dalam pengambilan keputusan. Dengan voting ini maka kualitas undang-undang ditentukan oleh partai besar yang menjadi dominasi dalam suatu negara. Hal inilah yang menjadi permasalahan dan keraguan tentang kualitas undang-undang yang telah dan akan diterapkan di dalam masyarakat.

Bilamana melihat penciptaan undang-undang di dominasi kepentingan-kepentingan maka secara tidak langsung undang-undang yang sudah ada menjadi pertanyaan akan kredibilitasnya dalam mengatur masyarakat. Masalah seperti inilah yang dihadapi oleh negara kita saat ini mengingat penciptaan undangundang masih didasari oleh kepentingan-kepentingan partai atau politik bukan mengutamakan kepentingan masyarakat banyak yang mana mencapai kepastian, keadilan dan manfaat. Mahfud M.D. mengatakan bahwa karena banyaknya kepentingan politik yang mempengaruhi, maka akhirnya undang-undang yang dibuat seringkali bertentangan dengan konstitusi dan akan diajukan ke Mahkamah Konstitusi untuk dijudicial review. Saat di sidang, para pembuatnya pun seringkali tidak bisa memberikan argumentasi yang kuat sehingga beberapa undang-undang akhirnya berakibat dibatalkan (Pendapat Mahfud M.D., Barter Kepentingan Politik dalam Pembuatan UU Masih Tinggi, Berita Satu, Rabu, 26 Desember 2012, Jam 18:43 WIB). Undang-undang yang seperti inilah yang nantinya akan menambah permasalahan hukum yang ada bukan menyelesaikan permasalahan hukum untuk menjadi lebih baik.

Selanjutnya, wewenang yang diberikan kepada para elit politik untuk membentuk suatu peraturan dijadikan alat untuk mencapai kepentingan politik mereka. Aspirasi rakyat sering terlupakan akibat terlalu sibuknya para elit politik dalam mengurusi partai politiknya masing-masing bukan mengurusi keinginan dan kesejahteraan dari rakyat. Keinginan masyarakat hanya terjutu pada keadilan yang dapat memberikan keseimbangan didalam kehidupan yang bermasyarakat. Jika kepastian hanya tergantung dari muatan kepentingan politik maka kualitas undangundang patut untuk diragukan. Berawal dari kepastian jika terjadi permasalahan, maka secara tidak langsung keadilan pun tidak akan tercapai dan kemudian tidak ada manfaat yang dapat untuk didistribusikan kepada masyarakat. Secara singkat, kesejahteraan itu tidak akan tercapai jika kualitas undang-undang dilandasi dengan muatan kepentingan-kepentingan elit politik bukan kepentingan masyarakat banyak. Hal ini jelas tidak akan mempengaruhi perubahan hukum yang ada demi kemajuan hukum yang diinginkan.

Jelas sudah jika undang-undang yang berlaku banyak yang menyimpang dari konstitusi bilamana kepentingan-kepentingan politik masih diutamakan dalam pembuatan undang-undang. Pancasila dan Undang-Undang Dasar 1945 merupakan dasar yang 
baik didalam pembuatan produk undang-undang. Seringkali para elit politik mengindahkan Pancasila dan UUD 45 sebagai pedoman dalam pembuatan undang-undang sehingga kualitas undang-undang masih diragukan akan kredibilitasnya. Mereka lebih mengutamakan kepentingan-kepentingan elit politik demi suatu tujuan politik mereka dan mengindahkan konstitusi yang menjadi dasar sistem hukum kita.

Dengan wewenang penuh para elit politik dalam menciptakan undang-undang, kewenangan inilah yang menentukan kualitas undang-undang yang ada sehingga muatan kepentingan-kepentingan politik menentukan kualitas undang-undang. Jika sudah terjadi demikian, maka konstitusi hanya jadi hiasan negara bukan menjadi pedoman dalam menciptakan undang-undang demi kepastian, keadilan dan manfaat. Jika telah terjadi demikian, maka perlunya strategi pembangunan hukum guna menciptakan hukum yang baik yang jauh dari kepentingan-kepentingan politik dan banyak mengutamakan kepentingan masyarakat banyak.

\section{Pemecahan Permasalahan}

Melihat dari analisa permasalahan di atas tentunya kita prihatin akan nasib bangsa kita ini. Akan tetapi kita tidak boleh lupa bahwa negara kita menganut asas demokrasi yang semua keputusan berdasarkan musyawarah dan juga voting. Dengan keadaan yang demikian itu maka timbul suatu permasalahan yang relevansinya dengan pembuatan dari undang-undang dalam politik hukum. Dengan permasalahan yang sedemikian rupa itu penulis mengajukan beberapa masukan ataupun usulan guna meminimalisir muatan kepentingan dalam mempengaruhi esensi terciptanya undang-undang yang pro dengan rakyat. Adapun beberapa masukan dalam pemecahan masalah di atas antara lain adalah:

Pertama, Perbaikan akan Sumber Daya Manusia. Sumber daya manusia merupakan hal yang terpenting dalam menjalankan kehidupan masyarakat yang lebih baik. Hal ini ditandai dengan semakin bagus sumber daya manusia juga akan semakin bagus pula kualitas tarap hidup manusia tersebut. Dalam relevansi dengan terciptanya undang-undang yang merupakan sarana bagi perubahan hidup di masyarakat, sumber daya manusia yang berkualitas merupakan modal utama demi tercipta regulasi yang baik yang pro rakyat.

Dalam politik hukum jika sumber daya manusia pembuat hukum ini berkualitas, maka terciptalah undang-undang yang baik, bagus dan mempunyai kompetensi yang tinggi untuk mengatur kehidupan bermasyarakat agar lebih baik. Selain itu pelaksana undang-undang law enforcement juga harus didukung dengan sumber daya manusia yang juga bekualitas sehingga undang-undang yang bagus itu ditopang dengan pelaksanaan dan juga penegakan yang bagus pula. Sehingga sumber daya manusia yang berkualitas merupakan modal utama untuk membangun bangsa yang lebih baik.

Kedua, Mengedepankan Keadilan (John Rawls, 1999:3). Berbicara mengenai keadilan merupakan pembicaraan panjang yang tak kunjung habisnya. Semua elemen masyarakat menginginkan kesamaam hak dan juga kesamaan derajat dalam menjalankan kehidupan berbangsa dan juga bernegara. Aristoteles berpendapat bahwa keadilan merupakan kesamaan hak yang dimiliki oleh semua kalangan masyarakat. Perlu kita tahu bahwa keadilan merupakan milik individu bukan milik golongan orang banyak. Dengan demikian mengedepankan keadilan merupakan faktor yang sangat sulit dikarenakan kesamaan hak ini sulit untuk diberlakukan secara adil karena keadilan hanya milik individu.

Tidak lepas dari itu, demi tegaknya hukum yang baik serta undang-undang yang pro dengan rakyat, tentukan politik hukum yang harus mengedepankan keadilan demi terciptanya undang-undang yang baik. Dengan mengedepankan kepentingan rakyat, para elit politik dalam menciptakan undang-undang tentunya harus mengesampingkan kepentingan politik yang dirasa mengganggu kualitas undang-undang yang ada. Demikian itu tentunya politik hukum sudah mengedepankan keadilan di atas kepentingan orang banyak demi terciptanya hukum yang dicita-citakan ius constituendum.

Ketiga, Mengedepankan Konstitusi dan Pancasila. Kontitusi merupakan dasar pijak suatu undang-undang agar mempunyai landasan yang kuat bagi undangundang tersebut sebagai sarana untuk perubahan masyarakat. Konstitusi dalam negara adalah sebuah sistem politik dan hukum bentukan pada pemerintahan negara, biasanya dikodifikasikan sebagai dokumen tertulis. Konstitusi ini lahir dari jiwa dan normanorma yang hidup di dalam masyarakat tersebut sehingga konstitusi merupakan cerminan bagi hati nurani masyarakat banyak. Konstitusi juga diyakini merupakan modal dasar bagi undang-undang atau hukum yang akan diberlakukan di dalam masyarakat agar tercipta hukum yang sesuai dengan kehendak masyarakat banyak.

Di negara kita mengenal apa yang disebut dengan konstitusi yaitu UUD 45 yang menjadi induk dari semua undang-undang yang ada. Memang dalam praktiknya dari undang-undang kita banyak yang 
bertentangan dengan konstitusi terbukti banyaknya yudicial review yang akan membatalkan berlakunya undang-undang tersebut. Bila terjadi demikian, maka konstitusi harusnya djadikan modal utama secara selektif dalam pembuatan undang-undang yang mana bersih dari kepentingan politik tetapi berpaku pada kepentingan rakyat banyak yaitu konstitusi.

Selain konstitusi negara kita juga mempunyai dasar untuk menjalankan kehidupan yang sesuai dengan harkat martabat orang banyak. Pancasila merupakan dasar dari negara Indonesia yang wajib dipatuhi dan dilaksanakan melalui pengamalan-pengamalan. Selain itu pula pancasila merupakan sumber dari segala sumber hukum yang ada di Indonesia. Sumber dari segala sumber hukum mengartikan bahwa semua hukum yang ada dan berlaku di Indonesia harus sesuai dengan nilai-nilai dari Pancasila itu tersebut. Pancasila terdiri dari lima pasal yang berbunyi sebagai berikut: Ketuhanan Yang Maha Esa; Kemanusiaan yang adil dan juga beradab; Persatuan Indonesia; Kerakyatan yang dipimpin oleh hikmat kebijaksanaan dalam permusyawaratan/perwakilan; Keadilan sosial bagi seluruh rakyat Indonesia.

Dari hasil analisis dan pemecahan masalah di atas diharapkan mampu sedikit banyak membenahi kualitas undang-undang yang akan diterapkan untuk mengatur masyarakat banyak. Undang-undang jika dibarengi dengan sumber daya manusia yang bagus, mengedepankan keadilan dan sesuai dengan konstitusi dan Pancasila nantinya akan menciptkan hukum baru yang sesuai dengan hati nurani bangsa Indonesia dan dapat dengan mudah mengatur segi-segi kehidupan bangsa Indonesia.

\section{PENUTUP}

\section{Kesimpulan}

Setelah kita lihat pembahasan di atas maka dapat disimpulkan secara singkat bahwa produk undangundang jika disusupi kepentingan-kepentingan politik atau partai politik, maka produk undang-undang ini dirasa gagal karena tidak mengindah aspirasi dan keinginan rakyat. Jelas sudah jika muatan kepentingan merupakan penentu dari kualitas undang-undang yang ada. Problematika hukum yang demikian ini tidak akan mampu untuk melakukan kemajuan hukum yang diinginkan karena muatan kepentingan politik masih mendominasi produk undang-undang yang ada.

Selain itu ada pemecahan masalah yang diajukan oleh penulis yaitu perubahan sumber daya manusia dalam pembuatan undang-undang atau law making, dalam pelaksanakan dari undang-undang atau law enforcement yang mengedepankan keadilan dan dalam landasan akan undang-undang yaitu konstitusi dan Pancasila yang seharusnya dikedepankan untuk menciptakan undang-undang yang baik yang sesuai dengan hati nurani bangsa Indonesia. Jika ketiga kunci penyelesaian masalah ini dikedepankan demi terciptanya undang-undang yang baik, maka jelas sudah undang-undang yang dibuat sebagai sarana untuk mengatur masyarakat akan berjalan lebih baik lagi dan sesuai dengan keinginan masyarakat banyak yang nantinya akan mempengaruhi pembangunan hukum dan juga masyarakat yang ada di Indonesia. Keinginan inilah yang selama ini dinanti-nantikan oleh masyarakat Indonesia guna menerapkan hukum yang pro dengan rakyat yang sesuai dengan keadilan dan kesamaan derajat di depan hukum equality before the law.

\section{Rekomendasi}

Dalam pemerintahan dari suatu negara sebaiknya kepentingan rakyat yang menjadi tujuan utama. Jika hal ini dapat tercapai maka kepastian, keadilan dan manfaat dapat berjalan seiring dalam membenahi problematika hukum yang ada. Muatan akan adanya kepentingan politik yang seharusnya dikesampingkan demi kualitas produk undang-undang yang lebih baik yang dapat memberikan kontribusi positif bagi kepentingan masyarakat banyak. Hal ini harus sesuai dengan konstitusi kita yaitu UUD 45 agar sesuai dengan jiwa masyarakat Indonesia. Saran yang utama bagi elit politik dalam menciptakan suatu undangundang harus mengedepankan keadilan, konstitusi, Pancasila, dan kepentingan orang banyak sehingga undang-undang yang terlahir dari para elit politik dapat menjadi sarana bagi perubahan masyarakat untuk menuju masyarakat yang adil makmur sesuai dengan cita-cita bangsa Indonesia.

\section{DAFTAR PUSTAKA}

Ali, Zainuddin, 2010, Metode Penelitian Hukum, Jakarta: Sinar Grafika.

Apeldoorn, L. J. Van, 1985, Pengantar Ilmu Hukum, Jakarta: Pradnya Paramita.

Dwiloka, Bambang, 2005, Teknik Menulis Karya Ilmiah, Jakarta: Rineka Cipta.

Fanani, Ahmad Zaenal, Teori Keadilan dalam Perspektif Filsafat Hukum dan Islam, Artikel, Hakim PA Martapura.

Friedmann W., 1990, Teori dan Filsafat Hukum, Cet. Pertama, Jakarta: Rajawali Pers.

Huijbers, Theo, 1995, Filsafat Hukum dalam Lintasan Sejarah, Cet. VIII, Yogyakarta: Kanisisus.

Kafrawi, 2009, Pengantar Ilmu Hukum, Studi di 
Pascasarjana Hukum Unmer Malang.

Kansil, 1989, Pengantar Ilmu Hukum dan Tata Hukum Indonesia, Jakarta: Balai Pustaka.

Mahfud M.D., Barter Kepentingan Politik dalam Pembuatan UU Masih Tinggi, Berita Satu, Rabu, 26 Desember 2012 jam 18:43 WIB.

Marzuki, Peter Mahmud, 2006, Penelitian Hukum, Cet. Kedua, Jakarta: Kencana.

Mertokusumo, Sudikno, 2002, Mengenal Hukum Suatu Pengantar, Yogyakarta: Liberty.

Moleong, Lexy J., 2010, Metodologi Penelitian Kualitatif, Bandung: Remaja Rosdakarya.

Nusantara, Abdul Hakim G., 1988, Politik Hukum Indonesia, Jakarta: Yayasan Lembaga Bantuan Hukum Indonesia.

Poerwadarminta W.J.S., 1986, Kamus Umum Bahasa Indonesia, Jakarta: Balai Pustaka.

Rawls, John, 1999, A Theory of Justice, revised edition, Oxford: OUP.
, 2006, Pemahaman Buku Teori Keadilan $A$ Theory Of Justice, Cetakan I, Yogyakarta: Pustaka Pelajar.

Sunggono, Bambang, 2002, Metodologi Penelitian Hukum, Cet. Keempat, Jakarta: Raja Grafindo Persada.

Suriasumantri, Jujun S., 2009, Filsafat Ilmu, Jakarta: Pustaka Sinar Harapan.

Tanya, Bernar L., 2011, Politik Hukum, Agenda Kepentingan Bersama, Yogyakarta: Genta Publishing.

Wignjosoebroto, Soetandyo, 2002, Hukum, Paradigma, Metode dan Masalah, Jakarta: Lembaga Studi dan Advokasi Masyarakat (ELSAM).

Wikipedia Bahasa Indonesia, ensiklopedia bebas, www.wikipedia.org/wiki/hukum_indonesia

http://www.asiamaya.com/konsultasi_hukum/ist_ hukum/definisi_hukum.htm. 